\title{
In Vitro Pituitary and Thyroid Cell Proliferation Assays and Their Relevance as Alternatives to Animal Testing
}

\author{
Barae Jomaa ${ }^{1}$, Jac M.M. J. G. Aarts ${ }^{1,2}$, Laura H. J. de Haan ${ }^{1}$, Ad A. C. M. Peijnenburg ${ }^{2}$, \\ Toine F. H. Bovee ${ }^{2}$, Albertinka J. Murk ${ }^{1}$, and Ivonne M.C. M. Rietjens ${ }^{1}$ \\ ${ }^{1}$ Division of Toxicology, Wageningen University, Wageningen, The Netherlands; ${ }^{2}$ RIKILT - Institute of Food Safety, \\ Wageningen, The Netherlands
}

\begin{abstract}
Summary
This study investigates the in vitro effect of eleven thyroid-active compounds known to affect pituitary and/or thyroid weights in vivo, using the proliferation of GH3 rat pituitary cells in the so-called "T-screen," and of FRTL-5 rat thyroid cells in a newly developed test denoted "TSH-screen" to gain insight into the relative value of these in vitro proliferation tests for an integrated testing strategy (ITS) for thyroid activity. Pituitary cell proliferation in the T-screen was stimulated by three out of eleven tested compounds, namely thyrotropin releasing hormone (TRH), triiodothyronine (T3) and thyroxine (T4). Of these three compounds, only T4 causes an increase in relative pituitary weight, and thus T4 was the only compound for which the effect in the in vitro assay correlated with a reported in vivo effect. As to the newly developed TSH-screen, two compounds had an effect, namely, thyroid-stimulating hormone (TSH) induced and T4 antagonized FRTL-5 cell proliferation. These effects correlated with in vivo changes induced by these compounds on thyroid weight. Altogether, the results indicate that most of the selected compounds affect pituitary and thyroid weights by modes of action different from a direct thyroid hormone receptor (THR) or TSH receptor (TSHR)-mediated effect, and point to the need for additional in vitro tests for an ITS. Additional analysis of the T-screen revealed a positive correlation between the THR-mediated effects of the tested compounds in vitro and their effects on relative heart weight in vivo, suggesting that the T-screen may directly predict this THR-mediated in vivo adverse effect.
\end{abstract}

Keywords: thyroid, pituitary, cell proliferation, organ weight, in vitro-in vivo correlation

\section{Introduction}

Endocrine disruption has been the source of considerable debate since 1991 when Ana Soto reported that man-made compounds could act as estrogen mimics (Soto et al., 1991), an observation that was popularized with the publication of Our Stolen Future by Theo Colborne in 1996. Although some environmental chemicals have been shown to affect endocrine activity in in vitro and in vivo test systems, there is still debate as to whether this activity can truly result in adverse effects to humans at realistic levels of exposure (Boas et al., 2006; Brucker-Davis, 1998; Leghait et al., 2010; Brouwer et al., 1998). So far, attention on the endocrine activity of chemicals has largely focused on estrogen disruption. An analysis of literature search results in Scopus ${ }^{\mathrm{TM}}$ reveals that, in the last decade, the majority of the papers published on endocrine disruption have focused on estrogen rather than on androgen or thyroid hormone disruption. This is in contrast to the number of chemicals listed on the Toxnet hazardous substance data bank (HSDB) as of 25 January 2013 which lists 159 chemicals for androgen, 352 chemicals for estrogen, and 924 chemicals for thyroid activity. This is a cause for concern as altered thyroid hormone (TH) levels can cause adverse effects such as decreased fertility and retarded development, especially of the bones and the brain (Poppe and Velkeniers, 2004; Wajner et al., 2009; Göthe et al., 1999; Aronson et al., 1990; Zoeller and Crofton, 2000).

Changes in thyroid hormone levels are also directly related to changes in cardiac output, heart rate, and systemic vascular

Received November 19, 2012; accepted in revised form February 15, 2013

Abbreviations

3-AT, 3-amino-1,2,4-triazole; BBBC, 6-tert-butyl-m-cresol; BMD, benchmark dose; BMDL, benchmark dose lower limit;

BMDS, benchmark dose software; BPF, bisphenol $F$; $\mathrm{EC}_{50}$, effective concentration $50 \%$; ER, estrogen receptor;

ETU, ethylenethiourea; IC $_{50}$, inhibitory concentration $50 \%$; IVIVC, in vitro-in vivo correlation; MMI, methimazole;

PTU, propylthiouracil; T3, triiodothyronine; T4, tetraiodothyronine; tetrac, tetraiodothyroacetic acid; TH, thyroid hormone;

TG 407, test guideline number 407; THR, thyroid hormone receptor; TRE, thyroid hormone response element;

$\mathrm{TRH}$, thyrotropin-releasing hormone; triac, triiodothyroacetic acid; bTSH, bovine thyroid-stimulating hormone 
Tab. 1: List of compounds used in this study with their main mode of action on the thyroid hormone system and concentration ranges used in the in vitro experiments

\begin{tabular}{|c|c|c|c|c|c|}
\hline Compound & Abbreviation & CAS No. & Description & Mode of Action & Concentration Range (nM) \\
\hline $\begin{array}{l}\text { Thyrotropin- } \\
\text { Releasing Hormone }\end{array}$ & $\mathrm{TRH}$ & $24305-27-9$ & Endogenous ligand & $\begin{array}{l}\text { Binds thyrotropin- } \\
\text { releasing hormone } \\
\text { receptor }\end{array}$ & $0.001-160,000$ \\
\hline $\begin{array}{l}\text { bovine Thyroid } \\
\text { Stimulating } \\
\text { Hormone }\end{array}$ & bTSH & $9002-71-5$ & Endogenous ligand & $\begin{array}{l}\text { Binds thyroid stimulating } \\
\text { hormone receptor }\end{array}$ & $0.001 \times 10^{-3}-143$ \\
\hline Triiodothyronine & T3 & $6893-02-3$ & Endogenous ligand & $\begin{array}{l}\text { Binds thyroid hormone } \\
\text { receptor }\end{array}$ & $0.001-1,000$ \\
\hline Thyroxine & T4 & $51-48-9$ & Endogenous ligand & $\begin{array}{l}\text { Binds thyroid hormone } \\
\text { receptor }\end{array}$ & $0.001-1,000$ \\
\hline Propylthiouracil & PTU & $51-52-5$ & Antithyroid drug & $\begin{array}{l}\text { Inhibits thyroid peroxidase } \\
\text { and deiodinase type } 1\end{array}$ & $1-100,000$ \\
\hline Methimazole & MMI & $60-56-0$ & Antithyroid drug & Inhibits thyroid peroxidase & $1-100,000$ \\
\hline Ethylene thiourea & ETU & $96-45-7$ & $\begin{array}{l}\text { Environmental } \\
\text { contaminant }\end{array}$ & $\begin{array}{l}\text { Inhibits thyroid } \\
\text { peroxidase }\end{array}$ & $0.01-100,000$ \\
\hline Aminotriazole & 3-AT & $61-82-5$ & $\begin{array}{l}\text { Environmental } \\
\text { contaminant }\end{array}$ & Inhibits thyroid peroxidase & $0.01-100,000$ \\
\hline $\begin{array}{l}\text { Sodium perchlorate } \\
\text { monohydrate }\end{array}$ & $\mathrm{NaClO}_{4} \cdot \mathrm{H}_{2} \mathrm{O}$ & $7791-07-3$ & $\begin{array}{l}\text { Environmental } \\
\text { contaminant }\end{array}$ & Inhibition of iodide uptake & $0.01-200,000$ \\
\hline Bisphenol F & BPF & $620-92-8$ & $\begin{array}{l}\text { Environmental } \\
\text { contaminant }\end{array}$ & Binds to estrogen receptor & $0.01-1,000$ \\
\hline 4,4'-Butylidenebis & BBBC & $85-60-9$ & $\begin{array}{l}\text { Environmental } \\
\text { contaminant }\end{array}$ & Unknown & $0.001-100$ \\
\hline
\end{tabular}

resistance (Zamoner et al., 2011). The clinical outcomes of such disturbances include arrhythmias, reduced exercise performance, and an increased risk of cardiovascular mortality (Klein and Ojamaa, 2001; Fazio et al., 2004).

Considering that thyroid hormones play a crucial role in the development of the human brain, bones, and gonads, in pregnancy as well as in cardiac pathogenesis, the possibility of alterations to the normal function of the thyroid system by xenobiotics could have substantial societal implications (Oppenheimer and Schwartz, 1997; Zoeller et al., 2002; Göthe et al., 1999; Aronson et al., 1990; Wagner et al., 2008; Gardiner-Hill, 1929; Mestman et al., 1974; Sugrue and Drury, 1980; Fazio et al., 2004; Char, 1996). For this reason, the Organization of Economic Cooperation and Development (OECD) has amended and validated its test guideline number 407 (TG 407) for repeated-dose 28-day oral toxicity studies in rodents to include endpoints relevant to the thyroid system, including histopathology of the pituitary and thyroid weight. Thyroid hormone levels in plasma or serum are included as an optional endpoint for the confirmation of toxicants with a mode of action related to the thyroid system (OECD, 2007). However, testing on animals raises issues related to ethics, high costs, long duration, and difficulties in the interpretation of inter-species data.
This has prompted research into suitable in vitro assays that, once validated, could serve as alternatives.

Wang et al. (2012) recently published an in-depth comparison of the proliferative response of different estrogen-responsive human cell lines with data on the in vivo change in uterine weight in the rat uterotrophic assay upon exposure to a series of model compounds. Proliferation of the MCF-7 human breast cancer cell line subclone MCF-7/BOS upon exposure to the test compounds appeared to be predictive for the in vivo effect on rat uterine weight resulting in a squared sample correlation coefficient of 0.85 (Wang et al., 2012). Hence, as in the case of the estrogen-responsive MCF-7 cell proliferation assay, called "E-screen" (Soto et al., 1992), in vitro proliferation correlates well with the in vivo increase in uterine wet weight. For thyroid hormone activity, the so-called "T-screen" has been developed, detecting proliferation of rat pituitary adenoma cells upon exposure to thyroid hormone receptor (THR)-active compounds, whereas in vivo pituitary weight is an endpoint for the disruption of thyroid activity (Gutleb et al., 2005; Umano et al., 2009; Sellers and Schänbaum, 1965). Given the correlation of the E-screen with uterine weight, the objective of the present study was to investigate the correlation between the effects of a series of model thyroid-active compounds on cell proliferation in the T-screen and in vivo data for their ef- 
Tab. 2: List of compounds used in this study and overview of in vivo data

Selection was based on significant in vivo change in either thyroid weight ( $\Delta$ thyroid wt) or pituitary weight $(\Delta$ pituitary wt) in rats. The direction of the changes and their magnitude are presented in Tables 3 and 4 . Two studies are included for the effect of TRH on thyroid weight so that both sexes are represented and two studies using different exposure periods are included for the effect of T4 on pituitary weight. M, male; F, female; OM, Osborne-Mendel; SD, Sprague-Dawley; DM, Dutch-Miranda; CR, Charles River; LEW, Lewis; WSTR, Wistar; IV, intravenous; IP, intraperitoneal; NA, not available.

\begin{tabular}{|c|c|c|c|c|}
\hline Compound & Ref. for $\Delta$ pituitary wt & Type of study & Ref. for $\Delta$ thyroid wt & Type of study \\
\hline \multirow[t]{2}{*}{$\mathrm{TRH}$} & Iglesias et al., 1985 & $\begin{array}{l}\text { 34-day repeated oral dose } \\
\text { with } S D \text { rats }(F, n=6)\end{array}$ & D’Angelo et al., 1975 & $\begin{array}{l}\text { 14-day repeated oral dose } \\
\text { with } C R \text { rats }(F, n=4)\end{array}$ \\
\hline & - & - & Connors et al., 1988 & $\begin{array}{l}\text { 6-day chronic IV dose with } \\
\text { SD rats }(M, n=4)\end{array}$ \\
\hline bTSH & NA & NA & Connors et al., 1988 & $\begin{array}{l}\text { 6-day chronic IV dose with } \\
\text { SD rats }(M, n=4)\end{array}$ \\
\hline T3 & Nedvídková et al., 1996 & $\begin{array}{l}\text { 20-day repeated oral dose } \\
\text { with WSTR rats }(M, n=6)\end{array}$ & Soukup et al., 2001 & $\begin{array}{l}\text { 6-month repeated IP dose } \\
\text { with } L E W \text { rats }(F, n=10)\end{array}$ \\
\hline \multirow[t]{2}{*}{ T4 } & OECD, 2006b & OECD TG 407 (M, F, n=10) & OECD, 2006b & OECD TG 407 (M, F, n=10) \\
\hline & $\begin{array}{l}\text { Sellers and Schänbaum, } \\
1965\end{array}$ & $\begin{array}{l}\text { 64-week repeated oral dose } \\
\text { with WSTR rats }(M, n=6)\end{array}$ & - & - \\
\hline PTU & OECD, 2006b & OECD TG 407 (M, F, n=10) & OECD, 2006b & OECD TG 407 (M, F, n=10) \\
\hline MMI & Moreira et al., 2005 & $\begin{array}{l}\text { 21-day repeated oral dose } \\
\text { with } D M \text { rats, }(M, F, n=10)\end{array}$ & Hood et al., 1999 & $\begin{array}{l}21 \text {-day repeated oral dose } \\
\text { with } S D \text { rats, }(M, n=4)\end{array}$ \\
\hline ETU & Lu and Staples, 1978 & $\begin{array}{l}\text { 9-day repeated oral dose } \\
\text { with } C R \text { rats }(F, n=6-12)\end{array}$ & $\begin{array}{l}\text { Graham and Hansen, } \\
1972\end{array}$ & $\begin{array}{l}\text { 30-day repeated oral dose } \\
\text { with OM rats }(M, n=10)\end{array}$ \\
\hline 3-AT & Umano et al., 2009 & OECD TG 407 (M, F, n=10) & Umano et al., 2009 & OECD TG 407 (M, F, n=10) \\
\hline $\mathrm{NaClO}_{4}$ & Stoker et al., 2006 & $\begin{array}{l}\text { 31-day repeated oral dose } \\
\text { with } C R \text { rats }(M, n=25)\end{array}$ & Siglin et al., 2000 & $\begin{array}{l}\text { 90-day repeated oral dose } \\
\text { with } S D \text { rats }(M, F, n=10)\end{array}$ \\
\hline BPF & Higashihara et al., 2007 & OECD TG 407 (M, F, n=10) & Higashihara et al., 2007 & OECD TG 407 (M, F, n=10) \\
\hline BBBC & Yamasaki et al., 2008 & OECD TG 407 (M, F, n=10) & Yamasaki et al., 2008 & OECD TG 407 (M, F, n=10) \\
\hline
\end{tabular}

fects on pituitary weight. Compounds that tested positive in the T-screen were further tested in the GH3-TRE-Luc reporter gene assay using the same cell line in order to find out if the observed proliferation was directly caused by activation of the thyroid hormone receptor (Freitas et al., 2011). GH3 cells express all thyroid nuclear receptor isoforms, with THR $\beta 2$ and THR $\alpha 1$ being, in order, the most abundant, which is in line with pituitary expression patterns (Hahn et al., 1999; Freitas, 2012; Yen et al., 1992). Since these receptors shuttle between the nucleus and the cytoplasm, THR-active compounds must be able to cross the cell membrane to have an effect (Mavinakere et al., 2012). The cellular uptake of TH-like compounds is mediated by specific plasma membrane transporters showing preferential transport of T4 or T3 or their metabolites (Hennemann et al., 2001). Very lipophilic compounds also can cross the cell membranes by passive diffusion.

Moreover, as thyroid weight is another endpoint in in vivo studies for thyroid hormone activity, an additional objective was to develop an in vitro counterpart (OECD, 2007). To this end, a physiologically-relevant assay based on thyroid stimulating hormone (TSH)-induced proliferation of cells from the FRTL-5 rat thyroid cell line was developed (denoted TSH-screen). This screen was subsequently used to explore parallels between the effects of the selected model thyroid-active compounds on in vitro FRTL-5 rat thyroid cell proliferation and their effects on in vivo rat thyroid weight. Changes in thyroid weight are associated mainly with hyperplasia and hypervascularization and, to a lesser extent, hypertrophy, thereby suggesting that proliferation assays may be able to reflect the in vivo effects (Martin et al., 1973; Kero et al., 2007).

Given the complexity of the in vivo hypothalamic-pituitarythyroid (HPT) axis, it may be expected that the T-screen and the newly developed TSH-screen may prove less predictive for effects on pituitary and thyroid weight in vivo than the E-screen is for effects on uterine weight in the uterotrophic assay. Thus, the ultimate aim of this study was to provide insight into the predictive potential and relative value of the two in vitro cell proliferation screens within an integrated testing strategy (ITS) for thyroid activity. 
Tab. 3: Effects of the selected model compounds on relative pituitary organ weight ( $\mathrm{mg} / 100 \mathrm{~g}$ body weight) in male rats compared to in vitro pituitary cell proliferation (T-screen)

Arrows indicate an increase $(\uparrow)$, decrease $(\downarrow)$, or $(\leftrightarrow)$ no change in relative thyroid weight. If available, the fold-change in mean response to the highest tested dose (HTD) compared to the unexposed controls also was presented. ${ }^{*}$ indicates a significance dose $(p<0.05)$ and ${ }^{* *}$ indicates high significance $(p<0.01)$ for fold change calculations. Benchmark doses associated with a $10 \%$ change in organ weight $\left(\mathrm{BMD}_{10}\right)$ were calculated and presented as the lower $95 \%$ confidence limit $\left(\mathrm{BMDL}_{10}\right)$. For the effect on cell proliferation in vitro, besides fold change and when applicable, $\mathrm{EC}_{50}$ values are shown. The highest tested concentrations (HTCs) also are represented and were chosen in such a way that they were not cytotoxic based on results from the resazurin assay. NA, not applicable. In vitro-in vivo correlation (IVIVC) was evaluated qualitatively and represented by +ve when the direction of change was similar in both situations, by 0 when there was no correlation, by -ve when the direction of change was opposite and by $\mathrm{X}$ when there was no significant change in both situations leading to an invalid correlation.

\begin{tabular}{|c|c|c|c|c|c|c|c|c|c|}
\hline \multirow[b]{3}{*}{ Compound } & \multicolumn{5}{|c|}{$\begin{array}{c}\text { Pituitary organ weight } \\
\text { (literature) }\end{array}$} & \multicolumn{3}{|c|}{$\begin{array}{l}\text { Pituitary cell proliferation } \\
\text { (T-screen) }\end{array}$} & \multirow[t]{3}{*}{ IVIVC } \\
\hline & \multicolumn{2}{|c|}{ Male } & \multicolumn{2}{|c|}{ Female } & \multirow[b]{2}{*}{$\begin{array}{c}\text { HTD } \\
\text { (mg/kg } \\
\text { bw/day) }\end{array}$} & \multirow[b]{2}{*}{$\begin{array}{l}\text { Fold } \\
\text { change }\end{array}$} & \multirow[b]{2}{*}{$\begin{array}{l}E C_{50} \\
(n M)\end{array}$} & \multirow[b]{2}{*}{$\begin{array}{l}\text { HTC } \\
(\mu \mathrm{M})\end{array}$} & \\
\hline & $\begin{array}{l}\text { Fold } \\
\text { change }\end{array}$ & $\begin{array}{c}\text { BMDL10 } \\
\text { (mg/kg } \\
\text { bw/day) }\end{array}$ & $\begin{array}{l}\text { Fold } \\
\text { change }\end{array}$ & $\begin{array}{c}\text { BMDL10 } \\
\text { (mg/kg } \\
\text { bw/day) }\end{array}$ & & & & & \\
\hline TRH & NA & NA & $\leftrightarrow$ & $\mathrm{X}$ & 50 & $1.4 \mathrm{x} \uparrow^{\star *}$ & 0.90 & 160 & 0 \\
\hline bTSH & NA & NA & NA & NA & NA & $\leftrightarrow$ & NA & 0.143 & NA \\
\hline T3 & $1.1 \mathrm{x} \uparrow$ & $x$ & NA & NA & 0.0005 & $5 \times \uparrow^{\star *}$ & 0.09 & 1 & 0 \\
\hline \multirow[t]{2}{*}{ T4 } & $\leftrightarrow$ & $x$ & $\leftrightarrow$ & $x$ & 1 & $4.3 \times \uparrow^{\star * *}$ & 1.73 & 1 & 0 \\
\hline & $1.3 x \uparrow^{* *}$ & NA & NA & NA & 0.012 & $4.3 x \uparrow^{\star *}$ & 1.73 & 1 & $+\mathrm{ve}$ \\
\hline PTU & $1.4 \mathrm{x} \uparrow^{* *}$ & NA & $1.4 \mathrm{x} \uparrow^{* *}$ & NA & 10 & $\leftrightarrow$ & NA & 100 & 0 \\
\hline MMI & $\leftrightarrow$ & $x$ & $\leftrightarrow$ & $x$ & 75 & $\leftrightarrow$ & NA & 100 & $x$ \\
\hline ETU & NA & NA & $1 \mathrm{x} \leftrightarrow$ & $x$ & 40 & $\leftrightarrow$ & NA & 100 & 0 \\
\hline 3-AT & $1.3 \times \uparrow^{\star *}$ & 38.97 & $1.2 x \uparrow^{*}$ & 51.31 & 125 & $\leftrightarrow$ & NA & 100 & 0 \\
\hline $\mathrm{NaClO}_{4}$ & $1 \mathrm{x} \leftrightarrow$ & $x$ & NA & NA & 500 & $\leftrightarrow$ & NA & 200 & $x$ \\
\hline BPF & $1.1 \times \uparrow$ & $x$ & $1.1 \times \uparrow$ & $x$ & 500 & $\leftrightarrow$ & NA & 1 & $x$ \\
\hline BBBC & $1 \mathrm{x} \leftrightarrow$ & $x$ & $1 \mathrm{x} \leftrightarrow$ & $\mathrm{x}$ & 125 & $\leftrightarrow$ & $x$ & 0.1 & $x$ \\
\hline
\end{tabular}

\section{Materials and methods}

\section{Compound selection}

Table 1 presents the list of compounds selected and the concentration range used in the in vitro experiments. BBBC was obtained from Wako Pure Chemical Industries (Tokyo, Japan), while all other compounds were obtained from Sigma-Aldrich Chemie (Zwijndrecht, The Netherlands). All chemicals were of high purity ( $\geq 95 \%$ ). With the exception of bTSH, which was diluted in phosphate buffered saline (pH 7.2) (PBS), all test chemicals were added from 500-fold concentrated stock solutions in dimethylsulfoxide (DMSO, Acros Organics, Geel, Belgium), resulting in a final concentration of DMSO of $0.2 \%$.

Compound selection was based on whether in vivo data for effects of the compounds on pituitary and/or thyroid weight were available (Tab. 2). The mode of action underlying the in- crease in organ weights was not used as a selection criterion, since the objective was to test whether the proliferation assays could replace in vivo assays detecting organ weight changes, as was shown feasible for the E-screen and in vivo effects on uterus weight (Wang et al., 2012). Changes in pituitary weight induced by the selected model compounds are presented in Table 3 , and changes in thyroid weight induced by these compounds are presented in Table 4.

\section{Cell culture}

GH3-TRE-Luc cells were cultured at $37^{\circ} \mathrm{C}$ in a humid atmosphere containing $5 \%(\mathrm{v} / \mathrm{v}) \mathrm{CO}_{2}$ and passaged twice a week in Dulbecco's Modified Eagle's medium: Ham's F12 (1:1) with 15 mM HEPES (DMEM:F12, Gibco, Paisley, Scotland) supplemented with $10 \%$ fetal calf serum (FCS, Gibco, Paisley, Scotland). The construction and validation of the GH3-TRELuc cells was previously described (Freitas et al., 2011). 
Tab. 4: Effects of the selected model compounds on relative thyroid organ weight ( $\mathrm{mg} / 100 \mathrm{~g}$ body weight) in male rats compared to in vitro thyroid cell proliferation (TSH-screen)

Arrows indicate an increase $(\uparrow)$, decrease $(\downarrow)$, or $(\leftrightarrow)$ no change in relative thyroid weight. If available, the fold-change in mean response to the highest tested dose (HTD) compared to the unexposed controls also was presented. * indicates a significance dose $(p<0.05)$ and ** indicates high significance $(\mathrm{p}<0.01)$ for fold change calculations. † TRH and bTSH were chronically administered intravenously to male rats at $240 \mu \mathrm{g} /$ day and $800 \mathrm{mlU} /$ day, respectively. Benchmark doses associated with a $10 \%$ change in organ weight (BMD 10$)$ were calculated and presented as the lower $95 \%$ confidence limit $\left(B M L_{10}\right)$. For the effect on cell proliferation in vitro, besides fold change and when applicable, $\mathrm{EC}_{50}$ values are shown. The highest tested concentrations (HTCs) are also represented and were chosen in such a way that they were not cytotoxic based on results from the resazurin assay. NA, not applicable. In vitro-in vivo correlation (IVIVC) was evaluated qualitatively and represented by +ve when the direction of change was similar in both situations, by 0 when there was no correlation, by -ve when the direction of change was opposite and by $\mathrm{X}$ when there was no significant change in both situations leading to an invalid correlation.

\begin{tabular}{|c|c|c|c|c|c|c|c|c|c|}
\hline \multirow[b]{3}{*}{ Compound } & \multicolumn{5}{|c|}{$\begin{array}{c}\text { Thyroid organ weight } \\
\text { (literature) }\end{array}$} & \multicolumn{3}{|c|}{$\begin{array}{l}\text { Thyroid cell proliferation } \\
\text { (T-screen) }\end{array}$} & \multirow[t]{3}{*}{ IVIVC } \\
\hline & \multicolumn{2}{|c|}{ Male } & \multicolumn{2}{|c|}{ Female } & \multirow[b]{2}{*}{$\begin{array}{c}\text { HTD } \\
\text { (mg/kg } \\
\text { bw/day) }\end{array}$} & \multirow[b]{2}{*}{$\begin{array}{l}\text { Fold } \\
\text { change }\end{array}$} & \multirow[b]{2}{*}{$\begin{array}{l}E C_{50} \\
(n M)\end{array}$} & \multirow[b]{2}{*}{$\begin{array}{l}\mathrm{HTC} \\
(\mu \mathrm{M})\end{array}$} & \\
\hline & $\begin{array}{c}\text { Fold } \\
\text { change }\end{array}$ & $\begin{array}{c}\text { BMDL10 } \\
\text { (mg/kg } \\
\text { bw/day) }\end{array}$ & $\begin{array}{l}\text { Fold } \\
\text { change }\end{array}$ & $\begin{array}{c}\text { BMDL }_{10} \\
\text { (mg/kg } \\
\text { bw/day) }\end{array}$ & & & & & \\
\hline \multirow[t]{2}{*}{ TRH } & NA & NA & $1.1 \mathrm{x} \uparrow$ & $x$ & 12.5 & $\leftrightarrow$ & NA & 160 & $x$ \\
\hline & $1.7 x \uparrow^{*}$ & NA & NA & NA & $\dagger$ & $\leftrightarrow$ & NA & 160 & 0 \\
\hline bTSH & $1.8 x \uparrow^{*}$ & NA & NA & NA & $\dagger$ & $1.6 x \uparrow^{* *}$ & 4.6 & 0.143 & $+v e$ \\
\hline T3 & NA & NA & $1.9 x \downarrow^{*}$ & NA & 0.15 & $\leftrightarrow$ & NA & 1 & 0 \\
\hline T4 & $\leftrightarrow$ & $x$ & $1.3 x \downarrow^{*}$ & 0.26 & 1 & $1.3 x \downarrow^{*}$ & 0.11 & 1 & $+v e$ \\
\hline PTU & $7.2 x \uparrow^{\star * *}$ & 0.02 & $7.7 x \uparrow^{* *}$ & 0.14 & 10 & $\leftrightarrow$ & NA & 100 & 0 \\
\hline MMI & $3.3 x \uparrow^{* *}$ & 0.11 & NA & NA & 50 & $\leftrightarrow$ & NA & 100 & 0 \\
\hline ETU & $2.7 x \uparrow^{* *}$ & 1.52 & NA & NA & 37.5 & $\leftrightarrow$ & NA & 100 & 0 \\
\hline 3-AT & $3 x \uparrow^{* *}$ & 3.86 & $3.7 x \uparrow^{* *}$ & 2.10 & 125 & $\leftrightarrow$ & NA & 100 & 0 \\
\hline $\mathrm{NaClO}_{4}$ & $1.3 x \uparrow^{* *}$ & 0.36 & $1.2 x \uparrow^{*}$ & 6.44 & 10 & $\leftrightarrow$ & NA & 200 & 0 \\
\hline BPF & $1.3 x \uparrow^{* *}$ & 30.28 & $1.2 x \uparrow$ & $x$ & 500 & $\leftrightarrow$ & NA & 1 & 0 \\
\hline BBBC & $1.2 x \uparrow$ & $x$ & $1.3 x \uparrow^{* *}$ & 5.02 & 125 & $\leftrightarrow$ & NA & 0.1 & 0 \\
\hline
\end{tabular}

FRTL-5, a rat thyroid cell line (obtained from CLS, Germany), was cultured as a monolayer in tissue-culture flasks (obtained from Corning, Badhoevedorp, The Netherlands) at $37^{\circ} \mathrm{C}$ in a humid atmosphere containing $5 \%(\mathrm{v} / \mathrm{v}) \mathrm{CO}_{2}$ and passaged once a week with an interim refresh of the medium, which consisted of Coon's Modified F-12 medium (obtained from Biochrom, Berlin, Germany), supplemented with 5\% FCS, and a mixture of six hormones (referred to as 6H5, reflecting the presence of 6 hormones and 5\% FCS). The six hormones included bTSH $(1 \mathrm{mIU} / \mathrm{ml})$, insulin $(10 \mu \mathrm{g} / \mathrm{ml})$, hydrocortisone $(10 \mathrm{nM})$, apo-transferrin $(5 \mu \mathrm{g} / \mathrm{ml})$, glycyl-L-histidyl-L-lysine acetate $(10 \mathrm{ng} / \mathrm{ml})$, and somatostatin $(10 \mathrm{ng} / \mathrm{ml})$. All these hormones were obtained from Sigma-Aldrich Chemie (Zwijndrecht, The Netherlands). This $6 \mathrm{H} 5$ cell culture medium was supplemented with $1 \mathrm{mM}$ non-essential amino acids, $2 \mathrm{mM}$ L-glutamine, $100 \mathrm{U} / \mathrm{ml}$ penicillin and $100 \mu \mathrm{g} / \mathrm{ml}$ streptomycin (Difco, Amsterdam, The Netherlands). Enzymatic passaging was performed using a cell detachment and disaggregation solution containing 20 units/ml collagenase, $0.075 \%$ trypsin, and $2 \%$ chicken serum (CTC) in PBS. Collagenase and chicken serum were obtained from Sigma-Aldrich Chemie (Zwijndrecht, The Netherlands) while trypsin was obtained from Difco (Amsterdam, The Netherlands).

\section{T-screen}

The T-screen was performed as previously described (Schriks et al., 2006) and using the rat GH3-TRE-Luc cell line. Compared to wild type GH3 cells, this cell line is stably transfected with a thyroid-hormone response element (TRE) driven luciferase expression construct, allowing for the comparison between cell proliferation and TRE-driven gene expression with the same cell line (Freitas et al., 2011). Briefly, GH3-TRE-Luc cells at $80 \%$ confluence were incubated for $48 \mathrm{~h}$ in serum-free PCM-0 medium, as originally described by Sirbasku (1991). 
PCM-0 consists of phenol red-free DMEM:F12 with $15 \mathrm{mM}$ HEPES, $10 \mu \mathrm{g} / \mathrm{ml}$ bovine insulin, $10 \mu \mathrm{M}$ ethanolamine, 10 $\mathrm{ng} / \mathrm{ml}$ sodium selenite, $10 \mu \mathrm{g} / \mathrm{ml}$ apo-transferrin, and 500 $\mu \mathrm{g} / \mathrm{ml}$ bovine serum albumin (BSA, obtained from SigmaAldrich Chemie, Zwijndrecht, The Netherlands). The cells were then harvested and plated at a density of 2,500 cells/ well on a 96-well plate. Following an attachment period of 2 to $3 \mathrm{~h}$, the cells were exposed in triplicate and for $96 \mathrm{~h}$ to a concentration range of the chemicals to be tested alone or in combination with $0.25 \mathrm{nM}$ T3. Subsequently, and following a 4-h incubation period with $10 \mu \mathrm{l} /$ well of $0.1 \mathrm{mg} / \mathrm{ml} \mathrm{re-}$ sazurin (obtained from Sigma-Aldrich Chemie, Zwijndrecht, The Netherlands) in PBS, cell proliferation was measured as relative fluorescence units (RFUs) resulting from the reduction of non-fluorescent resazurin to the fluorescent product resorufin. Fluorescence was measured at $\lambda \mathrm{ex}=530 \mathrm{~nm}$ and $\lambda \mathrm{em}=$ $590 \mathrm{~nm}$ on a SpectraMax M2 microplate reader (Molecular Devices, Menlo Park, CA, USA).

\section{TSH-screen}

FRTL-5 cells at $70 \%$ confluence and below passage 30 were incubated in serum-free, phenol red-free DMEM containing $0.2 \% \mathrm{BSA}$ for a period of $96 \mathrm{~h}$. The cells were then harvested and plated at a density of 5,000 cells/well on a 96-well plate in phenol red-free DMEM with insulin $(10 \mu \mathrm{g} / \mathrm{ml})$ and, following an attachment period of 2 to $3 \mathrm{~h}$, exposed to a concentration range of the chemicals to be tested alone or in combination with $1 \mathrm{mIU} / \mathrm{ml} \mathrm{bTSH}$, in triplicate, for $72 \mathrm{~h}$. Following this incubation, cell proliferation was measured $4 \mathrm{~h}$ after the addition of $10 \mu \mathrm{l} /$ well of $0.1 \mathrm{mg} / \mathrm{ml}$ resazurin as described above.

\section{GH3-TRE-Luc Reporter Gene Assay}

GH3-TRE-Luc cells at $80 \%$ confluence were incubated in serum-free PCM-0 medium for $24 \mathrm{~h}$. The cells were then harvested and plated at a density of 30,000 cells/well on a 96-well plate and, following an attachment period of 2 to 3 $\mathrm{h}$, exposed in triplicate for $24 \mathrm{~h}$ to a concentration range of the chemicals to be tested alone or in combination with $0.25 \mathrm{nMT3}$. To measure luciferase activity, cell culture medium was thoroughly aspirated, and the cells were lysed by addition of low salt buffer, which consisted of $10 \mathrm{mM}$ Tris (Invitrogen, Carlsbad, CA), $2 \mathrm{mM}$ dithiothreitol (DTT) and $2 \mathrm{mM}$ trans1,2-diaminocyclohexane-N,N, $\mathrm{N}^{\prime}, \mathrm{N}^{\prime}$-tetra-acetic acid monohydrate (obtained from Sigma-Aldrich Chemie, Zwijndrecht, The Netherlands) ( $\mathrm{pH}$ 7.8). Cell lysis was completed by one subsequent freeze-thaw cycle. Luciferase reagent, which consisted of $20 \mathrm{mM}$ tricine, $1.07 \mathrm{mM}\left(\mathrm{MgCO}_{3}\right)_{4} \cdot \mathrm{Mg}(\mathrm{OH})_{2} \cdot 5 \mathrm{H}_{2} \mathrm{O}$, $2.67 \mathrm{mM} \mathrm{MgSO}_{4}$ (all obtained from Sigma-Aldrich Chemie, Zwijndrecht, The Netherlands), 0.1 mM EDTA, 2 mM dithiothreitol (obtained from Merck, Darmstadt, Germany), 470 $\mu \mathrm{M}$ D-luciferin and $5 \mathrm{mM}$ ATP (both obtained from Duchefa Biochemie, Haarlem, The Netherlands) ( $\mathrm{pH} 7.8$ ), was adde $\mathrm{d}$ to the wells, and luciferase flash-kinetics activity was measured as relative luminescence units (RLUs) using a Luminoskan Ascent luminometer from Labsystems (Helsinki, Finland),

\section{Data analysis}

In the T-screen, GH3-TRE-Luc reporter gene assay and TSHscreen, data points are representative of at least two independent experiments and three replicate wells per data point in each experiment. Raw data from triplicate wells were averaged, converted to fold change over solvent control and represented graphically as the means of independent experiments with bars representing the standard error of that mean (SEM). The luminescent signal in the GH3-TRE-Luc reporter gene assay was normalized to cell viability as determined by a resazurin cell viability test with an incubation period of $2 \mathrm{~h}$. Non-linear curve fitting was done using the Hill equation with the help of GraphPad Prism software version 5.04 (GraphPad Software, San Diego, CA, USA). In vitro, $\mathrm{EC}_{50}$ values were calculated from the fitted models as the concentration of the tested compound that gave $50 \%$ of the maximal response.

For the in vivo data collected from literature, with included standard deviations and more than one dose level used, the benchmark dose (BMD) approach was used and BMDL (95\% lower confidence limit of the BMD) values with a relative deviation from the controls of $10 \%\left(\mathrm{BMDL}_{10}\right)$ were calculated using Benchmark Dose Software (BMDS) version 2.1.2 (US EPA, Washington, DC, USA). For organ weight changes that were significant $(\mathrm{p}<0.05)$ among dose levels, the curve fitting models used for in vivo BMDL calculations were based on either polynomial, power, or Hill equations, and the choice of the best model to fit the data was based on the highest $\mathrm{p}$-value for three tests, namely, homogenous variance, adequate modeling of the variance and model fit and when these p-values were similar across models, then a lower Akaike Information Criterion (AIC) value was used for selection. Models with a goodness of fit for the means with a p-value $<1$ were rejected. BMDL 10 calculations were based on data from male rats (except for TRH for which data from virgin females were used and ETU for which data from gestating females were used).

Doses of $0,50,100,500$, and $750 \mathrm{ppm}$ ETU in feed were converted to $0,2.5,5,25$, and $37.5 \mathrm{mg} / \mathrm{kg}$ bw/day, a T3 dose of $0.01 \mathrm{mg} / \mathrm{kg}$ was converted to $0.0005 \mathrm{mg} / \mathrm{kg}$ bw/day and a T4 dose of $0.25 \mathrm{mg} / \mathrm{kg}$ diet was converted to $0.012 \mathrm{mg} / \mathrm{kg}$ bw/day, based on the assumption that rats consume $5 \%$ of their body weight of food each day. $0.03 \%(0.3 \mathrm{mg} / \mathrm{ml}) \mathrm{MMI}, 0.2 \mathrm{mg} /$ $\mathrm{ml}$, and $0.05 \mathrm{mg} / \mathrm{ml} \mathrm{TRH}$ in drinking water were converted to $75 \mathrm{mg} / \mathrm{kg}$ bw, $50 \mathrm{mg} / \mathrm{kg}$ bw and $12.5 \mathrm{mg} / \mathrm{kg}$ bw, respectively, based on a previous study reporting an average water intake of similarly aged rats of $250 \mathrm{ml} / \mathrm{kg}$ bw (McGivern et al., 1996). To calculate the molar concentrations of bTSH, it was considered that TSH has a molar mass of $28,000 \mathrm{~g} / \mathrm{mol}$ and conversion to $\mathrm{mIU} / \mathrm{ml}$ was based on the manufacturer's stated activity of $2 \mathrm{IU} / \mathrm{mg}$ (Pierce et al., 1971).

\section{Results}

\subsection{Activity of selected compounds in the T-screen}

Figures $1 \mathrm{~A}$ and $1 \mathrm{C}$ show that the endogenous agonists $\mathrm{T} 3$ and $\mathrm{T} 4$, along with their respective acetic acid analogues triac and 
A

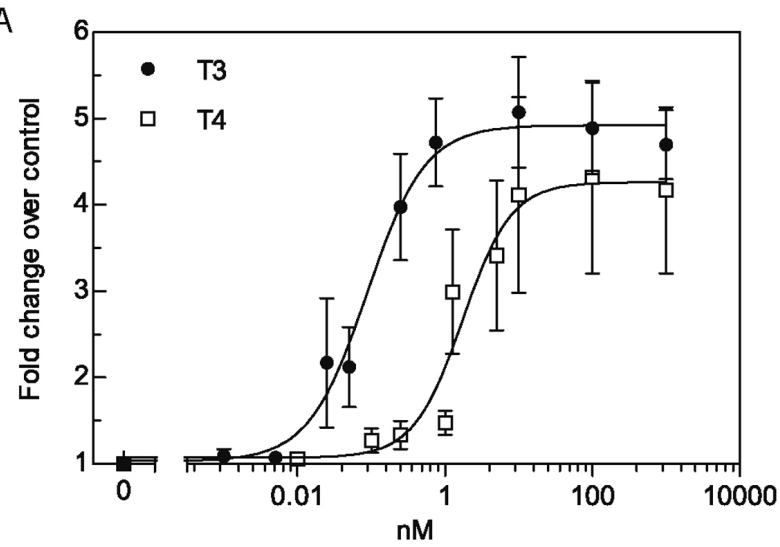

C

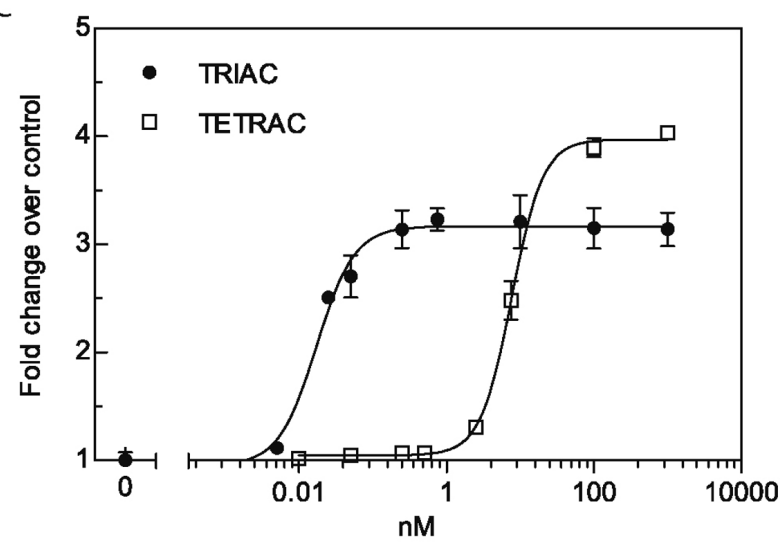

E

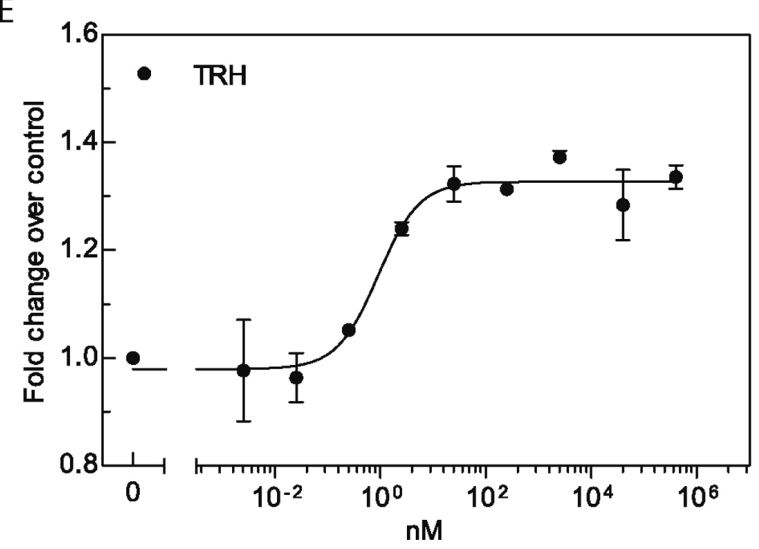

B

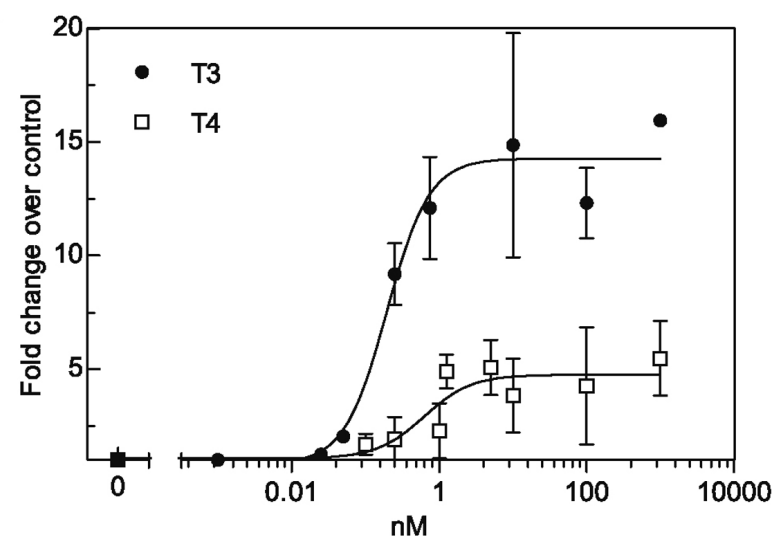

D

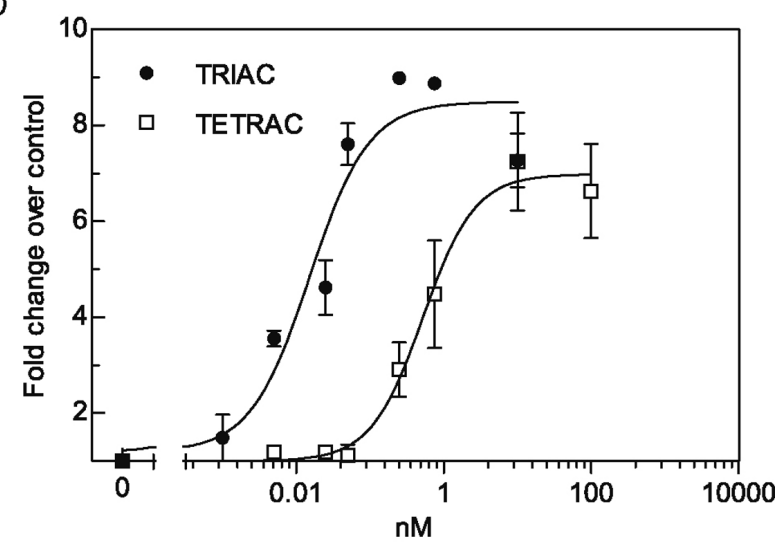

Fig. 1: Concentration-dependent GH3 cell proliferation

Concentration-dependent GH3 cell proliferation (T-screen) upon exposure to A) T3 (n=5) and T4 (n=3), C) triac ( $n=1)$ and tetrac $(n=1)$ or $E)$ TRH $(n=2)$ and luciferase response in the GH3-TRE-Luc thyroid hormone receptor reporter gene assay for $B)$ T3 $(n=3)$ and T4 $(n=2)$ or D) triac $(n=2)$ and tetrac $(n=2)$. The response is expressed as fold change over control, error bars represent the standard error of the mean (SEM) of the indicated number of independent experiments. 
tetrac resulted in a concentration-dependent increase in cell proliferation in the T-screen. Figures $1 \mathrm{~B}$ and $1 \mathrm{D}$ show that a concentration-dependent response also was obtained in the GH3TRE-Luc reporter gene assay, which is an indication that the observed cell proliferation is likely to be THR-mediated. The other model compounds tested with known in vivo effects on pituitary weight, propylthiouracil (PTU) and 3-amino-1,2,4-triazole (3-AT) did not induce a proliferative response in the assay for in vitro GH3 pituitary cell proliferation. On the other hand, $\mathrm{TRH}$, which does not lead to an increase in pituitary weight in vivo, was found to be an agonist in the T-screen with an $\mathrm{EC}_{50}$ of $0.9 \mathrm{nM}$ (95\% confidence interval 0.3-2.4 nM, Fig. 1E).

\subsection{Correlation of in vitro pituitary cell proliferation with in vivo pituitary weight}

Table 3 presents an overview of the effects of the selected model compounds on pituitary weight in in vivo studies derived from literature, as well as the results obtained in the present study on the effects of the compounds in the T-screen assay. A correlation between the in vitro T-screen and effects on pituitary weight reported in the in vivo studies was observed only for T4.

\subsection{Development of the TSH-screen based on FRTL-5 cell proliferation}

FRTL-5 cells are a differentiated, continuously growing, nontransformed subclone of FRTL rat thyroid cells derived from primary cultures of Fischer rat thyroid glands. Differentiated features such as the cellular uptake of iodide and the secretion of thyroglobulin in FRTL cells are dependent on a low concentration of FCS (0.5-1\%) which results in slow growth (AmbesiImpiombato et al., 1980). FRTL-5 is a fast growing subclone of the FRTL cell line that grows in 5\% FCS while maintaining iodide uptake and thyroglobulin secretion. In addition, FRTL-5 cells exhibit enhanced TSH sensitivity, especially after TSH starvation (Ambesi-Impiombato, 1986).

To optimize the proliferation of FRTL-5 cells, a series of compounds was tested for its ability to improve TSH-induced cell proliferation, subsequently defining cell culture conditions in the TSH-screen. As can be seen in Figure 2, FRTL-5 cells exhibited little response to bTSH $(1 \mathrm{mIU} / \mathrm{ml})$ alone and a limited response to insulin $(10 \mu \mathrm{g} / \mathrm{ml})$, while the combination of both TSH and insulin resulted in a synergistic effect. Forskolin, a compound that directly activates cAMP, the downstream target of TSH's proliferative action, also was tested alone or in combination with TSH (Kimura et al., 2001). The forskolin response closely mimicked that of TSH, and the combination of forskolin with insulin had an effect similar to that of TSH in combination with insulin, showing that the membrane receptor-mediated $\mathrm{TSH}$-response was near optimal and reflects the differentiated characteristics of this cell line. As little as $0.2 \%$ FCS had a proliferative effect that was larger than bTSH. The addition of apo-transferrin and hydrocortisone, which are needed in the culture of FRTL-5 cells, had little effect in terms of TSH-responsiveness of the cells (Ambesi-Impiombato, 1986). The addition of a somatostatin antibody, to block any inhibitory action of residual somatostatin, also had little effect (Medina et al., 1999). Based on these results, further testing

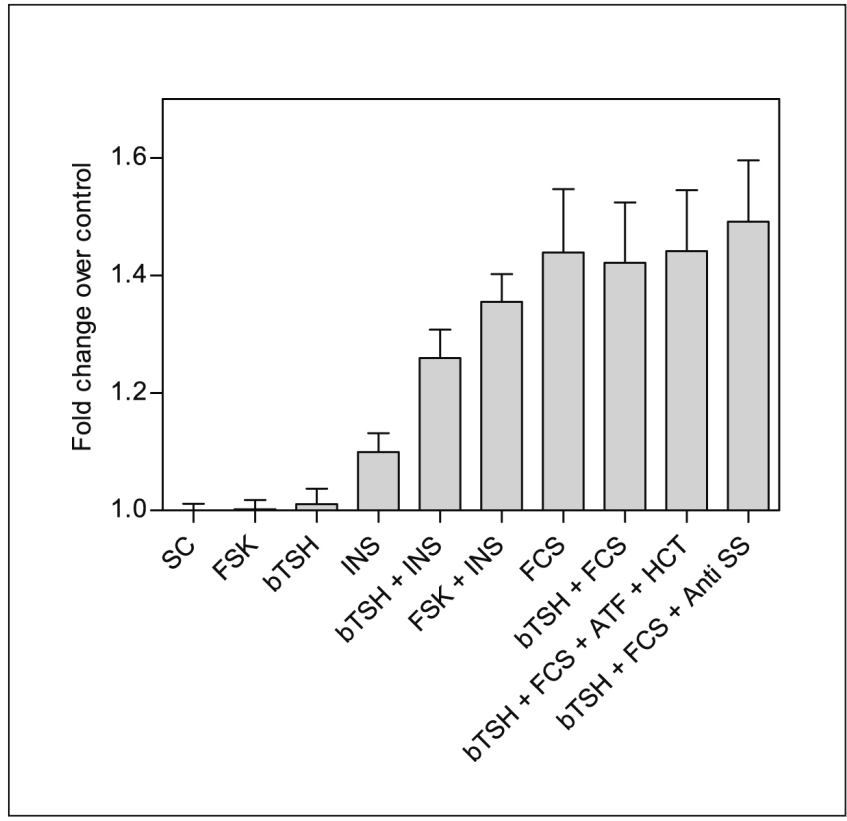

Fig. 2: FRTL-5 cell proliferation

FRTL-5 cell proliferation expressed as fold change over control upon exposure to $0.2 \% \mathrm{DMSO}$ as solvent control (SC), $0.1 \mu \mathrm{M}$ forskolin (FSK), $1 \mathrm{mIU} / \mathrm{ml}$ bovine thyrotopin (bTSH), $10 \mu \mathrm{g} / \mathrm{ml}$ insulin (INS), bTSH with INS, FSK and INS, $0.2 \%$ fetal calf serum (FCS), bTSH with $0.2 \%$ FCS, bTSH with $0.2 \%$ FCS in addition to $5 \mu \mathrm{g} / \mathrm{ml}$ apo-transferrin (ATF) and $10 \mathrm{nM}$ hydrocortisone (HCT), bTSH with $0.2 \% \mathrm{FCS}$ and $4 \mu \mathrm{g} / \mathrm{ml}$ antisomatostatin antibody (Anti SS), and lastly bTSH, $0.2 \%$ FCS, FSK and Anti SS $(n=1)$. Proliferation was measured as fluorescence resulting from the mitochondrial metabolism of resazurin to the fluorescent resorufin.

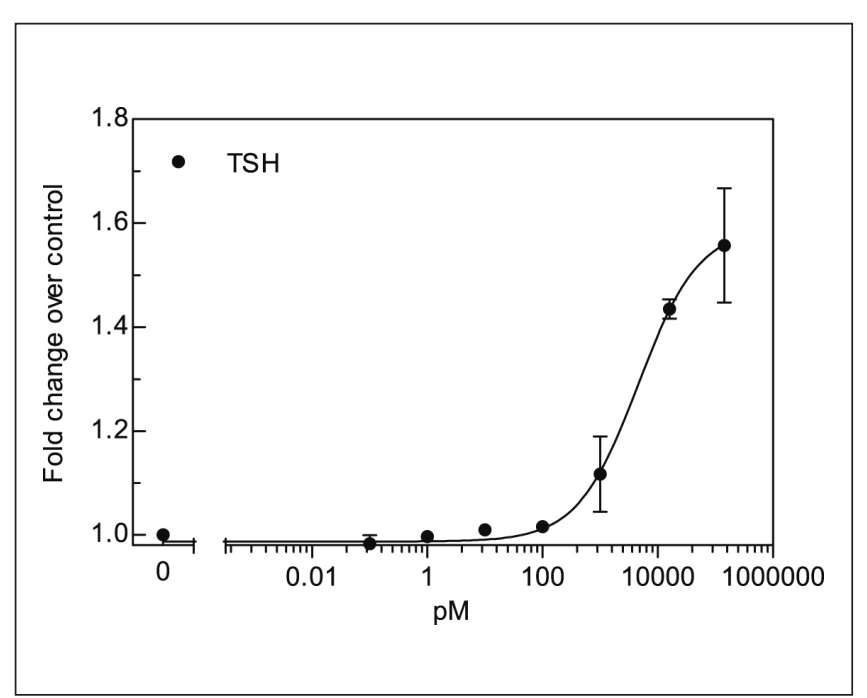

Fig. 3: TSH-induced FRTL-5 cell proliferation in the TSH screen

Proliferation is expressed as fold change over control, error bars represent the standard error of the mean (SEM) of two different experiments. 
using the TSH-screen was performed in serum-free medium containing insulin $(10 \mu \mathrm{g} / \mathrm{ml})$.

Figure 3 shows the TSH concentration-dependent proliferation of FRTL-5 cells in the newly developed TSH-screen. This response was achieved in cell culture medium completely devoid of serum but supplemented with $10 \mu \mathrm{g} / \mathrm{ml}$ insulin and $0.2 \%$ BSA. BSA is commonly added to serum-free media as it is thought to protect cells from agitation and aeration damage by biological and fluid-mechanical mechanisms (Papoutsakis, 1991; Michaels et al., 1995). The EC50 for TSH-dependent induction of cell proliferation was found to be $4.6 \mathrm{nM}$ (95\% confidence interval 1.7-12.6 nM).

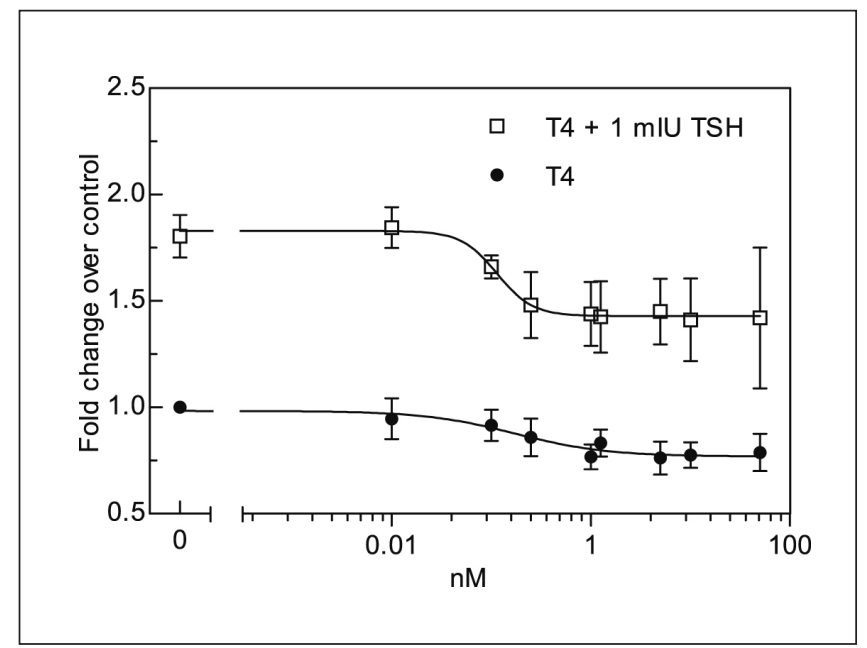

Fig. 4: Effect on proliferation of FRTL-5 cells

Effect of T4 $(n=3)$ on basal proliferation (closed circles) and TSH-induced proliferation (open circles) of FRTL- 5 cells.

\subsection{Activity of selected compounds in the TSH-screen}

In a next step, the series of model compounds was tested in the TSH-screen for either agonistic or antagonistic activity, the latter by testing cell proliferation in the presence of $1 \mathrm{mU}$ bTSH (14.3 nM). The TSH-screen only gave a significant response with the endogenous agonist TSH while T4 showed antagonism with an $\mathrm{IC}_{50}$ of $0.11 \mathrm{nM}$ (95\% confidence interval 0-0.4 nM, Fig. 4).

\subsection{Correlation of in vitro thyroid cell proliferation with in vivo thyroid weight}

Table 4 presents an overview of the effects of the selected model compounds on thyroid weight in in vivo studies, derived from literature, as well as the results obtained in the present study on the effects of the compounds in the TSH-screen. As can be observed from Table 4, the effects of the series of model compounds on in vitro FRTL-5 thyroid cell proliferation correlates in only a very limited number of cases with the effects of the compounds on thyroid weight in vivo. The endogenous agonist TSH was one of the two compounds that had a similar proliferative effect both in vitro and in vivo. The other compound, T4, acted in a potentially physiological manner since it reduced thyroid weight in vivo in female rats and showed an antagonistic activity in the TSH-screen, both with and without TSH (Fig. 5).

\subsection{Correlation of T-screen with cardiac hypertrophy}

Given that the effect of some of the thyroid-active model compounds on GH3 cell proliferation (T-screen) and THR activity (GH3-TRE-Luc reporter gene assay) could not be correlated to effects on pituitary weight in vivo, investigations into poten-
A

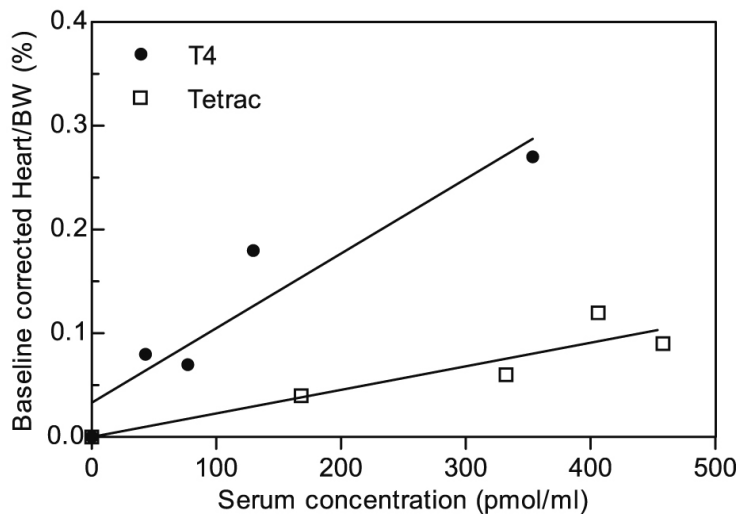

B

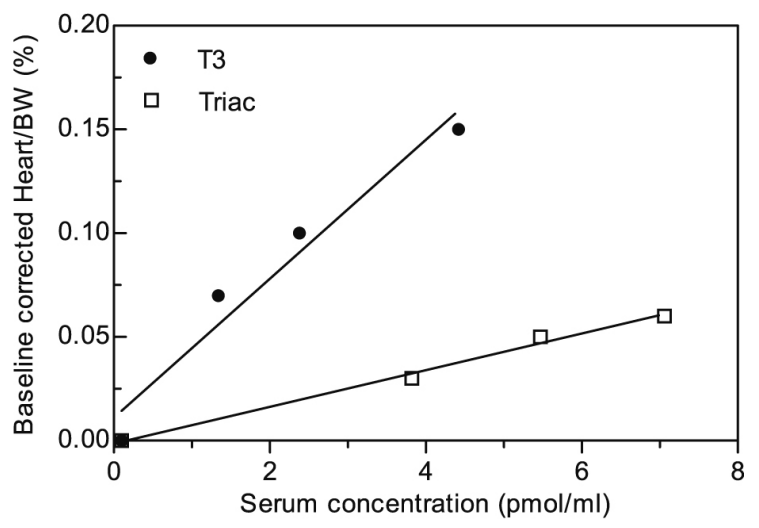

Fig. 5: Increase in relative heart weight

Effect of increasing serum levels of A) T4 and tetrac (data from Lameloise et al., 2001) and B) T3 and triac (data from Liang et al., 1997) on relative heart weight (expressed as $\%$ of total body weight). 
tial correlations with effects on other organs was carried out based on data retrieved from the literature. It was found that the proliferative response to thyroid-active compounds in the T-screen may correlate with the in vivo effects of these compounds on cardiac hyperthrophy. Figure 5 presents the plasma concentration-dependent effect of T4 and tetrac (Fig. 5A) and of T3 and triac (Fig. 5B) on relative heart weight as reported in literature (Liang et al., 1997; Lameloise et al., 2001). Comparison of these results with the results for $\mathrm{T} 3$, triac, $\mathrm{T} 4$ and tetrac mediated effects in the T-screen (Fig. 1A,C) indicates that the THR-mediated cell hyperplasia in the T-screen correlates well with the receptor-mediated cardiac hypertrophy (Fig. 6). This is corroborated by the results presented in Figure 6 in which the in vivo $\mathrm{BMDL}_{10}$ for $10 \%$ increase in relative heart weight in the in vivo studies was plotted against the $\mathrm{EC}_{50}$ for cell proliferation in the T-screen obtained in the present study, showing a correlation with a squared coefficient of correlation $\left(\mathrm{r}^{2}\right)$ of 0.89 . Thus, whereas activity of these thyroid-active compounds on pituitary cell proliferation in vitro in the T-screen did not correlate with their effects on pituitary weight in vivo, their activity in the T-screen did correlate with their effects on relative heart weight in vivo.

\section{Discussion}

The objective of the present study was to investigate a potential correlation between the effects of a series of model thyroidactive compounds on GH3 pituitary cell proliferation in the T-screen assay and their effects on pituitary weight in in vivo studies. Given that thyroid weight is one of the endpoints used in in vivo studies for thyroid hormone activity, an additional ob-

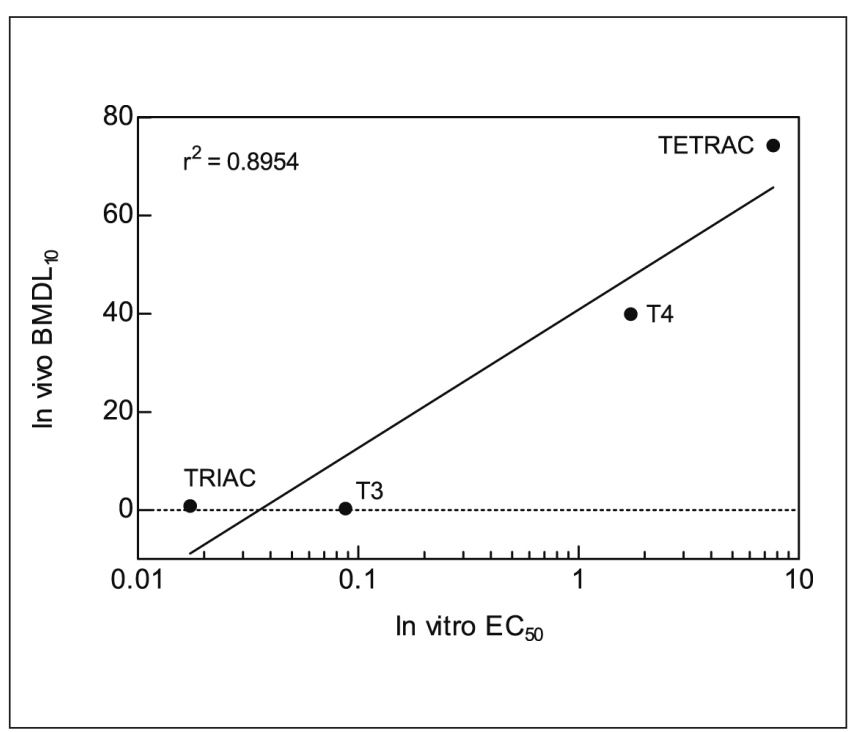

Fig. 6: Correlation between $\mathrm{EC}_{50}$ for T-screen and $\mathrm{BMDL}_{10}$ Correlation between $\mathrm{EC}_{50}$ for in vitro thyroid hormone-dependent GH3 pituitary cell proliferation (T-Screen) and $\mathrm{BMDL}_{10}$ for in vivo change in relative heart weight as induced by the compounds T3, $\mathrm{T} 4$, triac and tetrac. jective was to develop an in vitro thyroid cell proliferation assay and explore correlations between the in vitro data obtained and in vivo data for compounds known to affect thyroid weight (OECD, 2007). This was done in order to gain further insight into the relative value of these proliferative in vitro tests for an integrated testing strategy (ITS) for thyroid activity.

The newly developed TSH-screen was based on the proliferation of cells from the FRTL-5 cell line. The preservation of TSH-induced cell proliferation in the FRTL-5 cell line is a property exhibited by only three cell lines that originate from normal rat thyroid follicular epithelium. The other two cell lines, PC Cl3 and Wistar rat (WRT), have been reported to have a suitable TSH-mediated proliferative response but are not as widely used and are not commercially available (Fusco et al., 1987; Brandi et al., 1987; Kimura et al., 2001). The reference compound used in this screen, TSH, has been shown to result in cell hyperplasia and hypertrophy, both in FRTL-5 cells in vitro and in the thyroid gland in vivo (Ossendorp et al., 1989; Ambesi-Impiombato et al., 1980; Brewer et al., 2007). Figure 2 shows that insulin is needed for the mitogenic action of TSH and was included in both culture and exposure media used in the TSH-screen. While TSH is the main hormone that regulates the growth of the thyroid gland, the requirement for insulin has been well documented in both rodents and humans (Felice et al., 2004).

In a previous study, it was demonstrated that an in vitro-in vivo correlation (IVIVC) for endocrine-active compounds exists between estrogen-mediated cell proliferation in the so-called E-screen and in vivo effects on uterine weight (Wang et al., 2012). The relative potency of a series of estrogens for estrogen-induced MCF-7 cell proliferation in the E-screen correlated with the relative potency of the same compounds in the in vivo uterotrophic assay (Wang et al., 2012). In a detailed review paper on thyroid hormone disruption assays, the OECD mirrors a widely-held notion among toxicologists that the T-screen is an in vitro bioassay that can detect compounds that interfere with THR signaling much the way the MCF-7 cells are used in the E-screen to detect compounds that interfere with estrogen receptor (ER) signaling (OECD, 2006a). However, results obtained in this study show that this comparison between the T-screen and the E-screen is inaccurate when it comes to in vitro-in vivo correlation (IVIVC), since the activity of the selected model compounds in the T-screen did not correlate well with their in vivo effect on pituitary weight. Likewise, the in vivo effects of thyroid-active compounds on thyroid weight did not exhibit a consistent correlation with thyroid cell proliferation in a newly developed TSH-screen. The discrepancy between the two endocrine systems in terms of the applicability of the in vitro-in vivo extrapolation may be due to the fact that the uterotrophic assay for estrogen activity is based on ER-mediated increases in uterine weight, while increases in pituitary or thyroid weight may reflect much more complex mechanisms. These mechanisms include, among others, acute xenobioticinduced dyshormogenesis, displacement of thyroid hormones from transport proteins, changes in metabolism and clearance, alterations in feedback mechanisms, onset of autoimmune thyroiditis, effects on cofactors and inhibitors, as well as crosstalk 
with other pathways (Roy and Mugesh, 2006b; Cao et al., 2010; Gayrard et al., 2011; Zabka et al., 2011; Kosuda et al., 1997; Grover et al., 2007; Liu and Brent, 2010). Thus, with the exception of T4 and TSH, the effects of the selected thyroid-active compounds on pituitary and thyroid organ weights in vivo are not likely to be due to a direct effect on cell proliferation. The T-screen and TSH-screen are therefore less predictive for the effects of thyroid-active compounds on pituitary and thyroid weight in vivo than the E-screen is for the effects of estrogenic compounds on uterine weight in the uterotrophic assay.

Altogether, the results obtained indicate that while the Tscreen and the TSH-screen accurately reflect $\mathrm{TH}$ and TSH receptor-mediated cell proliferation, respectively, an integrated testing strategy for replacement of these in vivo endpoints by a battery of in vitro tests will need additional assays to cover mechanisms of action that are neither THR nor TSHR mediated. The known modes of action underlying the effects of these compounds are presented in the following text, thereby highlighting some of the critical issues that have to be accounted for with additional in vitro assays. Recently, a mechanism-based testing strategy has been proposed using a battery of in vitro assays for the identification of thyroid hormone disrupting chemicals (Murk et al., in press). The TSH-screen presented in this study is already included in the proposed battery as well, in addition to tests for NIS and cAMP production that play an important role in $\mathrm{TH}$ biosynthesis in thyrocytes.

TRH is a hypothalamic hormone whose main role is to stimulate the release of TSH and prolactin from the pituitary gland. TRH reaches the pituitary through the hypothalamic-hypophyseal portal system, triggering a signaling cascade by binding to the TRH receptor that eventually leads to TSH and prolactin secretion (De Léan et al., 1977). TRH is rapidly metabolized, resulting in a half-life of 4 minutes, rendering it undetectable in the systemic circulation (Redding and Schally, 1972; Bassiri and Utiger, 1973). It was previously shown in in vivo experiments performed on rats that TRH alone does not have a proliferative effect on pituitary cells, which is not in accordance with the results of the present study in which TRH did have an agonistic activity on GH3 cell proliferation (Quintanar-Stephano and Valverde, 1997). TRH did not have any proliferative effect on FRTL-5 thyroid follicular cells in the TSH-screen even though in vivo thyroid weight is increased. The in vivo effect can be simply an indirect effect, whereby TRH leads to an increase in TSH secretion which, in turn, is mitogenic to thyroid cells, a sequence of events that is not easily mimicked in vitro.

$\mathrm{TSH}$, the pituitary hormone whose main role is to stimulate thyroid growth and thyroid hormone production, had no effect on $\mathrm{GH} 3$ cell proliferation in the T-screen, which is in agreement with previous studies (Felice et al., 2004; Theodoropoulou et al., 2000). It did, nonetheless, exhibit a physiologically relevant and concentration-dependent mitogenic effect on FRTL-5 cells in the TSH-screen.

$\mathrm{T} 3$ and T4, the thyroid hormones, resulted in a concentrationdependent increase in GH3 pituitary cell proliferation, which is the basis of the T-screen (Gutleb et al., 2005). However, only T4 leads to a significant increase in pituitary weight in vivo, and this increase was found to be heavily dependent on the dura- tion of exposure (Tab. 3). The endogenous THR agonist precursor T4 causes a significant increase in pituitary weight but only after long-term exposure of more than one year, while in the OECD TG 407, which is based on subacute exposure (28 days), no significant effect is found (Sellers and Schänbaum, 1965; OECD, 2006b). This stands in contrast to the 4-fold increase in GH3 pituitary cell proliferation observed upon exposure to T4 for only 4 days (Fig. 1A). The effect of T3 on FRTL-5 rat thyroid cell proliferation was indistinguishable from the controls, and this does compare well with the lack of change in thyroid weight upon T3 administration. T4 had an antagonistic effect in the TSH-screen, which correlated significantly but only with female rats used in one of the in vivo studies conducted by the OECD to validate the updated TG 407 (OECD, 2006b). It is possible that $\mathrm{T} 4$, an iodinated hormone precursor that is deiodinated intrathyroidally, acts in a similar way to iodide, which is known to lead to cell cycle arrest in FRTL-5 cells (Laurberg, 1988; Smerdely et al., 1993). Moreover, amiodarone, a T4 analogue, has an inhibitory effect on TSH-induced cAMP production at concentrations that are lower than iodide, suggesting a direct mechanism of action (Pitsiavas et al., 1999). This in vitro effect could indicate a physiologically relevant short-feedback regulatory loop.

Antithyroid drugs PTU and MMI, the degradation product of ethylenebisdithiocarbamate fungicide ETU, as well as the herbicide 3-AT, decrease serum levels of thyroid hormones by inhibiting thyroperoxidase (TPO), a critical enzyme in thyroid hormone synthesis (Roy and Mugesh, 2006a; Marinovich et al., 1997; Hurley, 1998). The increase in thyroid weight resulting from the in vivo administration of these compounds and the increase in pituitary weight resulting from the administration of PTU and 3-AT are not related to a direct effect on cell proliferation as was reflected in this study by the T-screen and the TSH-screen. It can therefore be concluded that their effect may rather be due to a drop in thyroid hormone production, which in turn diminishes the inhibitory effect of $\mathrm{T} 4$ on pituitary weight and triggers an increase in TSH secretion by the pituitary and a subsequent mitogenic effect on the thyroid.

$\mathrm{NaClO}_{4}$, a non-reactive electrolyte under physiological conditions, exerts its effect on the thyroid by inhibiting iodide transport through the sodium iodide symporter (NIS), resulting in a drop in the iodide-dependent thyroid hormone production (Yoshida et al., 1998). In vivo, this drop in thyroid hormone levels results in decreased negative feedback on the thyroid and a concomitant increase in TSH secretion, which in turn results in an increase in thyroid weight. Pituitary weight is not affected, nor is pituitary or thyroid cell proliferation as assessed by the T-screen and the TSH-screen, respectively.

$\mathrm{BPF}$, widely used in the production of polycarbonate and epoxy resins, causes liver toxicity and was found to be estrogenic in the uterotrophic assay. Following the OECD TG 407 which includes endpoints for thyroid hormone disruption, Higashihara et al. found effects on thyroid hormone level in addition to changes in thyroid and pituitary weight (Higashihara et al., 2007). While the exact mechanism of action is not yet elucidated, BPF did not affect cell proliferation in both the T-screen and the TSH-screen, suggesting that its main mechanism of ac- 
tion is not THR or TSHR-mediated. Initial data, as suggested by the authors of the in vivo study, pointed at a possible effect on thyroid hormone metabolism in the liver which can lead to compensatory TSH production which could ultimately lead to goiter and thyroid hyperplasia (Curran and DeGroot, 1991).

Altogether, it is concluded that unlike the direct in vitro-in vivo correlation that can be made with the E-screen, which tests for the estrogenic activity of compounds, proliferation of pituitary and thyroid cells is representative of only a small part of an array of mechanisms of actions involved in thyroid hormone disruption.

Interestingly, however, additional results of the present study indicated a possible correlation between the effects of thyroidactive compounds on cell proliferation in the T-screen and relative heart weight in vivo (Fig. 6). This correlation between the T-screen and cardiac hypertrophy may align well with studies on both GH3 cells and the heart. The adult rodent heart expresses $70 \%$ THR $\alpha 1$ and $30 \%$ THR $\beta 1$. It was found that THR $\beta$ knockout (KO) mice did not exhibit a T3-mediated increase in left ventricular heart mass whereas THR $\alpha$ KO mice did (Swanson et al., 2003; Weiss et al., 2002). This indicates that THR $\beta$ expression is a requirement in the well-established thyroid hormoneinduced cardiac hypertrophy.

There are more factors affecting cardiac hypertrophy such as the renin-angiotensin system. However, this system is itself regulated by thyroid hormones (Diniz et al., 2009). Makino et al. (2009) reported that cardiac capillary networks are reduced in THR $\beta$ KO mice but not in THR $\alpha$ KO mice. Taken together, these studies indicate that THR $\beta$-regulated cardiac hypertrophy acts together with THR $\beta$-mediated angiogenesis to result in an overall effect on heart weight that is dominated by thyroid hormone agonism of THR $\beta$. In GH3 cells, these effects are likely to be mediated by THR $\beta 2$ - the predominant isoform in pituitary cells (Lazar, 1990; Ball et al., 1997; Hahn et al., 1999). Regardless of the mechanism of action, the thyroid hormone-dependent cell proliferation that is the hallmark of the T-screen correlates more closely with in vivo heart weight than with in vivo pituitary weight. This correlation between in vivo $\mathrm{BMDL}_{10}$ and in vitro $\mathrm{EC}_{50}$, could be expanded to compare absolute effect levels by taking toxicokinetics into account whereby the in vivo blood levels are calculated from the in vivo exposure levels, as has been done recently for estrogenic effects (Punt et al., 2013).

\section{Conclusion}

In vitro pituitary and thyroid cell proliferation assays are not viable substitutes for assessing pituitary and thyroid organ weight change, respectively. This calls into question the use of thyroid hormone-dependent cell proliferation assays and related TR-mediated reporter gene assays as alternative in vitro tests for the in vivo effect of chemicals on the HPT axis. When these THR-activation tests turn out negative, this study indicates that there is a considerable chance of a false negative result with the compound still affecting thyroid or pituitary weight in vivo. Nonetheless, the present study has found that the T-screen has potential applications in assessing the effects of compounds on thyroid hormone-mediated cardiac hypertrophy. In the context of the 3 Rs (refinement, reduction, or replacement of animal studies), it is concluded that it is not currently feasible to have simple standalone in vitro replacements for in vivo tests for the disruption of the thyroid system. The results of the present study indicate that a complex interplay between factors within the HPT axis may underlie the effects of thyroid-active compounds on thyroid and pituitary organ weight endpoints in vivo. Therefore, it is concluded that the development of future alternative tests, aiming at refinement, reduction, or replacement of animal studies should include a broad battery of in vitro tests that cover the various modes of action of thyroid-active compounds as an initial screen and/or use more complex model systems that more closely reflect an intact HPT axis such as the nematode Caenorhabditis elegans or the vertebrate Danio rerio. Tests with both organisms can be performed in such a way that they are still considered alternatives to animal testing in higher vertebrates such as mouse and rat (Van der Ven, 2009).

\section{References}

Ambesi-Impiombato, F. S., Parks, L.A., and Coon, H. G. (1980). Culture of hormone-dependent functional epithelial cells from rat thyroids. Proc Natl Acad Sci U S A 77, 3455-3459.

Ambesi-Impiombato, F. S. (1986). Living, fast-growing thyroid cell strain, FRTL-5. US Patent 4608341.

Aronson, R., Ehrlich, R. M., Bailey, J. D., et al . (1990). Growth in children with congenital hypothyroidism detected by neonatal screening. J Pediatr 116, 33-37.

Ball, S. G., Ikeda, M., and Chin, W. W. (1997). Deletion of the thyroid hormone B1 receptor increases basal and triiodothyronine-induced growth hormone messenger ribonucleic acid in GH3 cells. Endocrinology 138, 3125-3132.

Bassiri, R. M. and Utiger, R. D. (1973). Metabolism and excretion of exogenous thyrotropin-releasing hormone in humans. J Clin Invest 52, 1616-1619.

Boas, M., Feldt-Rasmussen, U., Skakkebaek, N. E., et al. (2006). Environmental chemicals and thyroid function. Eur J Endocrinol 154, 599-611.

Brandi, M. L., Rotella, C. M., Mavilia, C., et al. (1987). Insulin stimulates cell growth of a new strain of differentiated rat thyroid cells. Mol Cell Endocrinol 54, 91-103.

Brewer, C., Yeager, N., and Di Cristofano, A. (2007). Thyroidstimulating hormone - Initiated proliferative signals converge in vivo on the mTOR kinase without activating AKT. Cancer Res 67, 8002-8006.

Brouwer, A., Morse, D. C., Lans, M. C., et al. (1998). Interactions of persistent environmental organohalogens with the thyroid hormone system: Mechanisms and possible consequences for animal and human health. Toxicol Ind Health 14, 59-84.

Brucker-Davis, F. (1998). Effects of environmental synthetic chemicals on thyroid function. Thyroid 8, 827-856.

Cao, J., Lin, Y., Guo, L. H., et al. (2010). Structure-based investigation on the binding interaction of hydroxylated poly- 
brominated diphenyl ethers with thyroxine transport proteins. Toxicology 277, 20-28.

Char, D. H. (1996). Thyroid eye disease. Br J Ophthalmol 80, 922-926.

Colborn, T. and Clement, C. (eds.) (1992). Chemically induced alterations in sexual and functional development: the wildlife/human connection. Vol. 1. New Jersey, USA: Princeton Scientific Publishing.

Connors, J. M., Huffman, L. J., and Hedge, G. A. (1988). Effects of thyrotropin on the vascular conductance of the thyroid gland. Endocrinology 122, 921-929.

Curran, P. G. and DeGroot, L. J. (1991). The effect of hepatic enzyme-inducing drugs on thyroid hormones and the thyroid gland. Endocr Rev 12, 135-150.

D’Angelo, S. A., Wall, N. R., Bowers, C. Y., et al. (1975). Effects of acute and chronic administration of TRH on TSH and prolactin secretion in normal and hypothyroid rats. Neuroendocrinology 18, 161-175.

De Léan, A., Ferland, L., Drouin, J., et al. (1977). Modulation of pituitary thyrotropin releasing hormone receptor levels by estrogens and thyroid hormones. Endocrinology 100, 14961504.

Diniz, G. P., Carneiro-Ramos, M. S., and Barreto-Chaves, M. L. M. (2009). Angiotensin type 1 receptor mediates thyroid hormone-induced cardiomyocyte hypertrophy through the Akt/GSK-3beta/mTOR signaling pathway. Basic Res Cardiol 104, 653-667.

Fazio, S., Palmieri, E. A., Lombardi, G., et al. (2004). Effects of thyroid hormone on the cardiovascular system. Recent Prog Horm Res 59, 31-50.

Felice, M. D., Postiglione, M. P., and Lauro, R. D. (2004). Minireview: Thyrotropin receptor signaling in development and differentiation of the thyroid gland: Insights from mouse models and human diseases. Endocrinology 145, 4062-4067.

Freitas, J., Cano, P., Craig-Veit, C., et al. (2011). Detection of thyroid hormone receptor disruptors by a novel stable in vitro reporter gene assay. Toxicol In Vitro 25, 257-266.

Freitas, J. (2012). Development and validation of in vitro bioassays for thyroid hormone receptor mediated endocrine disruption. $\mathrm{PhD}$ thesis. Wageningen University. http://edepot. wur.nl/240578

Fusco, A., Berlingieri, M. T., Di Fiore, P. P., et al. (1987). Oneand two-step transformations of rat thyroid epithelial cells by retroviral oncogenes. Mol Cell Biol 7, 3365-3370.

Gardiner-Hill, H. (1929). Pregnancy complicating simple goiter and Graves' disease. Lancet 213, 120-124.

Gayrard, V., Picard-Hagen, N., Viguié, C., et al. (2011). Competitive binding to plasma thyroid hormone transport proteins and thyroid disruption by phenylbutazone used as a probe. Gen Comp Endocr 174, 225-231.

Göthe, S., Wang, Z., Ng, L., et al. (1999). Mice devoid of all known thyroid hormone receptors are viable but exhibit disorders of the pituitary-thyroid axis, growth, and bone maturation. Genes Dev 13, 1329-1341.

Graham, S. L. and Hansen, W. H. (1972). Effects of short-term administration of ethylenethiourea upon thyroid function of the rat. B Environ Contam Tox 7, 19-25.
Grover, G. J., Dunn, C., Nguyen, N.-H., et al. (2007). Pharmacological profile of the thyroid hormone receptor antagonist NH3 in rats. J Pharm Exp Ther 322, 385-390.

Gutleb, A. C., Meerts, I. A. T. M., Bergsma, J. H., et al . (2005). T-Screen as a tool to identify thyroid hormone receptor active compounds. Environ Toxicol Pharmacol 19, 231-238.

Hahn, C. G., Pawlyk, A. C., Whybrow, P. C., et al. (1999). Differential expression of thyroid hormone receptor isoforms by thyroid hormone and lithium in rat GH3 and B103 cells. Biol Psychiat 45, 1004-1012.

Hennemann, G., Docter, R., Friesema, E. C. H., et al. (2001). Plasma membrane transport of thyroid hormones and its role in thyroid hormone metabolism and bioavailability. Endocr Rev 22, 451-476.

Higashihara, N., Shiraishi, K., Miyata, K., et al. (2007). Subacute oral toxicity study of bisphenol $\mathrm{F}$ based on the draft protocol for the "Enhanced OECD Test Guideline no. 407". Arch Toxicol 81, 825-832.

Hood, A., Liu, Y. P., Gattone $2^{\text {nd }}$, V. H., et al. (1999). Sensitivity of thyroid gland growth to thyroid stimulating hormone (TSH) in rats treated with antithyroid drugs. Toxicol Sci 49, 263-271.

Hurley, P. M. (1998). Mode of carcinogenic action of pesticides inducing thyroid follicular cell tumors in rodents. Environ Health Perspect 106, 437-445.

Iglesias, R., Llobera, M., and Montoya, E. (1985). Sequential changes in the pituitary thyroid axis after chronic TRH administration: effects on euthyroid and thyroxine treated female rats. Acta Endocrinol 109, 237-242.

Kero, J., Ahmed, K., Wettschureck, N., et al. (2007). Thyrocytespecific Gq/G11 deficiency impairs thyroid function and prevents goiter development. J Clin Invest 117, 2399-2407.

Kimura, T., Van Keymeulen, A., Golstein, J., et al. (2001). Regulation of thyroid cell proliferation by TSH and other factors: A critical evaluation of in vitro models. Endocr Rev 22, 631656.

Klein, I. and Ojamaa, K. (2001). Thyroid hormone and the cardiovascular system. $N$ Engl J Med 344, 501-509.

Kosuda, L. L., Greiner, D. L., and Bigazzi, P. E. (1997). Effects of $\mathrm{HgCl}_{2}$ on the expression of autoimmune responses and disease in diabetes-prone (DP) BB rats. Autoimmunity 26, 173-187.

Lameloise, N., Siegrist-Kaiser, C., O’Connell, M., et al. (2001). Differences between the effects of thyroxine and tetraiodothyroacetic acid on TSH suppression and cardiac hypertrophy. Eur J Endocrinol 144, 145-154.

Laurberg, P. (1988). Amiodarone inhibits T4 and T3 secretion but does not affect T4 deiodination to T3 in perfused dog thyroid lobes. Thyroidology 1, 1-4.

Lazar, M. A. (1990). Sodium butyrate selectively alters thyroid hormone receptor gene expression in GH3 cells. J Biol Chem 265, 17474-17477.

Leghait, J., Gayrard, V., Toutain, P. L., et al. (2010). Is the mechanisms of fipronil-induced thyroid disruption specific of the rat: Re-evaluation of fipronil thyroid toxicity in sheep? Toxicol Lett 194, 51-57.

Liang, H., Juge-Aubry, C. E., O’Connell, M., et al. (1997). Or- 
gan-specific effects of 3,5,3'-triiodothyroacetic acid in rats. Eur J Endocrinol 137, 537-544.

Liu, Y. Y. and Brent, G. A. (2010). Thyroid hormone crosstalk with nuclear receptor signaling in metabolic regulation. Trends Endocrinol Metab 21, 166-173.

Lu, M. H. and Staples, R. E. (1978). Teratogenicity of ethylenethiourea and thyroid function in the rat. Teratology 17, 171-178.

Makino, A., Suarez, J., Wang, H., et al. (2009). Thyroid hormone receptor-beta is associated with coronary angiogenesis during pathological cardiac hypertrophy. Endocrinology 150, 2008-2015.

Marinovich, M., Guizzetti, M., Ghilardi, F., et al. (1997). Thyroid peroxidase as toxicity target for dithiocarbamates. Arch Toxicol 71, 508-512.

Martin, L., Finn, C. A., and Trinder, G. (1973). Hypertrophy and hyperplasia in the mouse uterus after oestrogen treatment: An autoradiographic study. J Endocrinol 56, 133-144.

Mavinakere, M. S., Powers, J. M., Subramanian, K. S., et al. (2012). Multiple novel signals mediate thyroid hormone receptor nuclear import and export. J Biol Chem 287, 3128031297.

McGivern, R. F., Henschel, D., Hutcheson, M., et al. (1996). Sex difference in daily water consumption of rats: Effect of housing and hormones. Physiol Behav 59, 653-658.

Medina, D. L., Velasco, J. A., and Santisteban, P. (1999). Somatostatin is expressed in FRTL-5 thyroid cells and prevents thyrotropin-mediated down-regulation of the cyclin-dependent kinase inhibitor P27kip1. Endocrinology 140, 87-95.

Mestman, J. H., Manning, P. R., and Hodgman, J. (1974). Hyperthyroidism and pregnancy. Arch Intern Med 134, 434-439.

Michaels, J. D., Nowak, J. E., Mallik, A. K., et al. (1995). Interfacial properties of cell culture media with cell-protecting additives. Biotechnol Bioeng 47, 420-430.

Moreira, D. G., Marassi, M. P., Corrêa da Costa, V. M., et al. (2005). Effects of ageing and pharmacological hypothyroidism on pituitary-thyroid axis of Dutch-Miranda and Wistar rats. Exp Gerontol 40, 330-334.

Murk, A., Rijntjes, E., Blaauboer, B., et al. (in press). Mechanism-based testing strategy using in vitro and in silico approaches for identification of thyroid hormone disrupting compounds. Toxicol In Vitro.

Nedvídková, J., Pacák, K., Nedvidek, J., et al. (1996). Triiodothyronine attenuates estradiol-induced increases in dopamine D-2 receptor number in rat anterior pituitary. Brain Res $712,148-152$.

OECD (2006a). Detailed review paper on thyroid hormone disruption assays. OECD Environment, Health and Safety Publications, Paris.

OECD (2006b). Report on the validation of the updated test guideline 407: Repeat dose 28-day oral toxicity study in laboratory rats. OECD Environmental Health and Safety Publications, Paris.

OECD (2007). Draft updated test guideline 407: Repeated dose 28-day oral toxicity study in rodents; updated with parameters for endocrine effects. Organisation for Economic Cooperation and Development, Paris.
Oppenheimer, J. H. and Schwartz, H. L. (1997). Molecular basis of thyroid hormone-dependent brain development. Endocr Rev 18, 462-475.

Ossendorp, F. A., Leer, L. M., Bruning, P. F., et al. (1989). Iodination of newly synthesized thyroglobulin by FRTL-5 cells is selective and thyrotropin dependent. Mol Cell Endocrinol 66, 199-205.

Papoutsakis, E. T. (1991). Media additives for protecting freely suspended animal cells against agitation and aeration damage. Trends Biotechnol 9, 316-324.

Pierce, J. G., Liao, T., Howard, S. M., et al. (1971). Studies on the structure of thyrotropin: its relationship to luteinizing hormone. Recent Prog Horm Res 27, 165-212.

Pitsiavas, V., Smerdely, P., and Boyages, S. C. (1999). Amiodarone compared with iodine exhibits a potent and persistent inhibitory effect on TSH-stimulated cAMP production in vitro: a possible mechanism to explain amiodarone-induced hypothyroidism. Eur J Endocrinol 140, 241-249.

Poppe, K. and Velkeniers, B. (2004). Female infertility and the thyroid. Best Pract Res Cl En 18, 153-165.

Punt, A., Brand, W., Murk, A. J., et al. (2013). Effect of combining in vitro estrogenicity data with kinetic characteristics of estrogenic compounds on the in vivo predictive value. Toxicol In Vitro 27, 44-51.

Quintanar-Stephano, A. and Valverde, C. (1997). Mitogenic effects of thyroxine and TRH on thyrotrophs and somatotrophs of the anterior pituitary gland in thyroidectomized rats. $J$ Endocrinol 154, 149-153.

Redding, T. W. and Schally, A. V. (1972). On the half life of thyrotropin-releasing hormone in rats. Neuroendocrinology 9, 250-256.

Roy, G. and Mugesh, G. (2006a). Bioinorganic Chemistry in Thyroid Gland: Effect of Antithyroid Drugs on PeroxidaseCatalyzed Oxidation and Iodination Reactions. Bioinorg Chem Appl 2006, 1-9.

Roy, G. and Mugesh, G. (2006b). Thyroid hormone synthesis and anti-thyroid drugs: A bioinorganic chemistry approach. $J$ Chem Sci 118, 619-625.

Schriks, M., Vrabie, C. M., Gutleb, A. C., et al. (2006). T-screen to quantify functional potentiating, antagonistic and thyroid hormone-like activities of poly halogenated aromatic hydrocarbons (PHAHs). Toxicol In Vitro 20, 490-498.

Sellers, E. A. and Schänbaum, E. (1965). Further studies on the goitrogenic action of thyroxine administered with propylthiouracil, methimazole or perchlorate. Acta Endocrinol 49, 319-330.

Siglin, J. C., Mattie, D. R., Dodd, D. E., et al. (2000). A 90-day drinking water toxicity study in rats of the environmental contaminant ammonium perchlorate. Toxicol Sci 57, 61-74.

Sirbasku, D. A. (1991). Thyroid hormone dependent pituitary tumor cell growth in serum-free chemically defined culture. A new regulatory role for apotransferrin. Biochemistry 30, 7466-7477.

Smerdely, P., Pitsiavas, V., and Boyages, S. C. (1993). Evidence that the inhibitory effects of iodide on thyroid cell proliferation are due to arrest of the cell cycle at G0G1 and G2M phases. Endocrinology 133, 2881-2888. 
Soto, A. M., Justicia, H., Wray, J. W., Sonnenschein, C. (1991). p-Nonyl-phenol: an estrogenic xenobiotic released from "modified" polystyrene. Environ Health Perspect 92, 16773.

Soto, A. M., Lin, T. M., Justicia, H., et al. (1992). An "in culture" bioassay to assess the estrogenicity of xenobiotics (escreen). In T. Colborn and C. Clement (eds.), ChemicallyInduced Alterations in Sexual and Functional Development: The Wildlife/Human Connection (295-309). Princeton, NY: Princeton Scientific Pub. Co.

Soukup, T., Zacharová, G., Smerdu, V., et al. (2001). Body, heart, thyroid gland and skeletal muscle weight changes in rats with altered thyroid status. Physiol Res 50, 619-626.

Stoker, T. E., Ferrell, J. M., Laws, S. C., et al. (2006). Evaluation of ammonium perchlorate in the endocrine disruptor screening and testing program's male pubertal protocol: ability to detect effects on thyroid endpoints. Toxicology 228, 58-65.

Sugrue, D. and Drury, M. I. (1980). Hyperthyroidism complicating pregnancy: results of treatment by antithyroid drugs in 77 pregnancies. Br J Obstet Gynaecol 87, 970-975.

Swanson, E. A., Gloss, B., Belke, D. D., et al. (2003). Cardiac expression and function of thyroid hormone receptor beta and its PV mutant. Endocrinology 144, 4820-4825.

Theodoropoulou, M., Arzberger, T., Gruebler, Y., et al. (2000). Thyrotrophin receptor protein expression in normal and adenomatous human pituitary. J Endocrinol 167, 7-13.

Umano, T., Shiraishi, K., Minobe, Y., et al. (2009). Uterotrophic assay, Hershberger assay, and subacute oral toxicity study of 3-amino-1,2,4-triazole based on the Organization for Economic Co-operation and Development draft protocols. Arch Toxicol 83, 459-467.

Van der Ven, L. (2009). Lower organisms as alternatives for toxicity testing in rodents; with a focus on Ceanorhabditis elegans and the zebrafish (Danio rerio). The National Institute for Public Health and the Environment (RIVM), Bilthoven. http://www.rivm.nl/bibliotheek/rapporten/340720003.pdf

Wagner, M. S., Wajner, S. M., and Maia, A. L. (2008). The role of thyroid hormone in testicular development and function. $J$ Endocrinol 199, 351-365.

Wajner, S. M., Wagner, M. S., and Maia, A. L. (2009). Clinical implications of altered thyroid status in male testicular function. Arq Bras Endocrinol Metabol 53, 976-982.

Wang, S., Aarts, J. M. M. J. G., Evers, N. M., et al. (2012). Proliferation assays for estrogenicity testing with high predictive value for the in vivo uterotrophic effect. J Steroid Biochem Mol Biol 128, 98-106.

Weiss, R. E., Korcarz, C., Chassande, O., et al. (2002). Thyroid hormone and cardiac function in mice deficient in thyroid hormone receptor-A or -B: An echocardiograph study. Am J Physiol Endocrinol Metab 283, E428-E435.

Yamasaki, K., Miyata, K., Shiraishi, K., et al. (2008). Uterotrophic assay, Hershberger assay, and subacute oral toxicity study of 4,4'-butylidenebis(2-tert-butyl-5-methylphenol) and 3 -(dibutylamino)phenol, based on the OECD draft protocols. Arch Toxicol 82, 301-311.

Yen, P. M., Sunday, M. E., Darling, D. S., et al. (1992). Isoformspecific thyroid hormone receptor antibodies detect multiple thyroid hormone receptors in rat and human pituitaries. Endocrinology 130, 1539-1546.

Yoshida, A., Sasaki, N., Mori, A., et al. (1998). Differences in the electrophysiological response to I- and the inhibitory anions SCN- and ClO-4, studied in FRTL-5 cells. Biochim Biophys Acta 1414, 231-237.

Zabka, T. S., Fielden, M. R., Garrido, R., et al. (2011). Characterization of xenobiotic-induced hepatocellular enzyme induction in rats anticipated thyroid effects and unique pituitary gland findings. Toxicol Pathol 39, 664-677.

Zamoner, A., Pessoa-Pureur, R., and Silva, F. R. M. B. (2011). Membrane-initiated actions of thyroid hormones on the male reproductive system. Life Sci 89, 507-514.

Zoeller, R. T. and Crofton, K. M. (2000). Thyroid hormone action in fetal brain development and potential for disruption by environmental chemicals. Neurotoxicology 21, 935-945.

Zoeller, T. R., Dowling, A. L. S., Herzig, C. T. A., et al. (2002). Thyroid hormone, brain development, and the environment. Environ Health Perspect 110, Suppl 3, 355-361.

\section{Acknowledgements}

This project was financially supported by the Netherlands Genomics Initiative (Netherlands Toxicogenomics Centre, grant number 6162500134). The authors would like to thank Katerina Kademoglou and Qian Zhang for their participation in the project during their MSc studies.

\section{Correspondence to}

Barae Jomaa, MSc

Postbus 8000

6700 EA Wageningen, Building 92

The Netherlands

Phone: +31 317482137

Fax: +31 317484931

e-mail: barae.jomaa@wur.nl 